\title{
Infection by Platynosomum illiciens (= P. fastosum) in domestic cats of Araguaína, Tocantins, northern Brazil
}

\author{
Infecção por Platynosomum illiciens (= P. fastosum) em gatos domésticos de Araguaína, \\ Tocantins, Norte do Brasil
}

Maria Cirlene Gomes de Oliveira Sobral'; Sebastiana Adriana Pereira Sousa²; Taiá Mairon Peixoto Ribeiro ${ }^{3,4}$; Samara Rocha Galvão ${ }^{4}$; Ruth Martins Santos ${ }^{4}$; Ronaira Assunção da Silva ${ }^{4}$; Thássia Silva Reis ${ }^{4}$;

Francisca Elda Ferreira Dias ${ }^{1,4}$; Helcileia Dias Santos ${ }^{1,4}$ [D

\begin{abstract}
${ }^{1}$ Programa de Pós-graduação em Sanidade Animal e Saúde Pública nos Trópicos, Escola de Medicina Veterinária e Zootecnia, Universidade Federal do Tocantins - UFT, Campus de Araguaína, Araguaína, TO, Brasil

${ }^{2}$ Cursos de Medicina Veterinária e Zootecnia, Universidade Federal do Sul e Sudeste do Pará - UNIFESSPA, Xinguara, PA, Brasil

${ }^{3}$ Programa de Pós-graduação em Ciência Animal, Universidade Federal de Goiás - UFG, Goiânia, GO, Brasil

${ }^{4}$ Curso de Medicina Veterinária, Escola de Medicina Veterinária e Zootecnia, Universidade Federal do Tocantins - UFT, Campus de Araguaína, Araguaína, TO, Brasil
\end{abstract}

Received April 21, 2019

Accepted August 1, 2019

\begin{abstract}
Platynosomiasis is a hepatopathy caused by Platynosomum illiciens ( $P$ P. fastosum) (Trematoda: Dicrocoelidae), which occurs mainly in domestic and wild cats in tropical and subtropical areas. The objective of this study was to verify the occurrence of $P$. illiciens infection in domestic cats in the city of Araguaína, Tocantins, Brazil, using necropsy and coproparasitological tests. Additionally, we aimed to evaluate the use of two different techniques to diagnose $P$. illiciens infection in domestic cats and verify whether this parasitism was associated with individual feline characteristics. For this, 54 cats of different ages were analyzed. The percentage of infection was $33.3 \%(\mathrm{CI}=21.1-47.5 \%)$, parasite load was 9-509, mean intensity was 151.7 , and mean abundance was 50.5 trematodes per animal. The risk of infection was higher for females than for males $(\mathrm{OR}=5.00 ; \mathrm{P}=0.017)$. The spontaneous sedimentation coproparasitological test demonstrated the greatest sensitivity and specificity in diagnosing $P$. illiciens. This study is the first to report the occurrence of $P$. illiciens in cats in the state of Tocantins, northern Brazil.
\end{abstract}

Keywords: Trematodes, Felis silvestris catus, platynosomiasis, frequency of infection, Amazônia.

\section{Resumo}

A platinosomose é uma hepatopatia causada por Platynosomum illiciens(= P. fastosum) (Trematoda: Dicrocoelidae), que ocorre principalmente em felinos domésticos e selvagens de áreas tropicais e subtropicais. O objetivo deste trabalho foi verificar a ocorrência de P. illiciens em gatos domésticos do município de Araguaína, Tocantins, Brasil, por meio de necrópsia e exames coproparasitológicos, bem como avaliar o uso de diferentes técnicas no diagnóstico de $P$. illiciens em gatos domésticos e verificar a associação da parasitose com características individuais dos felinos. O estudo foi realizado em 54 gatos com diferentes idades, machos e fêmeas. O percentual de infecçáo foi de 33,3\% (IC= 21,1\% - 47,5\%), a carga parasitária observada foi de 09-509, a intensidade média de 151,7 e a abundância média de 50,5 trematódeos por animal. As fêmeas apresentaram maior chance de infecção do que os machos $(\mathrm{OR}=5,00 ; \mathrm{P}=0,017)$. $\mathrm{O}$ teste coproparasitológico que demonstrou maior sensibilidade e especificidade foi o de sedimentaçáo espontânea. O presente estudo faz o primeiro relato da ocorrência de $P$. illiciens em gatos no estado do Tocantins, região Norte do Brasil.

Palavras-chave: Trematódeos, Felis silvestris catus, platinosomose, frequência de infecção, Amazônia.

Platynosomiasis, also known as "lizard poisoning," is a common feline liver disease caused by trematodes of the genus Platynosomum Looss, 1907. The names Platynosomum fastosum, P. concinnum, and

*Corresponding author: Helcileia Dias Santos. Laboratório de Parasitologia e Doenças Parasitárias, Escola de Medicina Veterinária e Zootecnia, Universidade Federal do Tocantins - UFT, Campus de Araguaína, BR 153, Km 112,

CEP 77804-970, Araguaína, TO, Brasil. e-mail: hdsantos@uft.edu.br
P. illiciens were used as synonyms in several studies, however, the use of $P$. illiciens is the most correct (PINTO et al., 2018). This parasite affect the liver, gallbladder, and bile ducts of domestic and wild cats (RAMOS et al., 2017), birds (RODRIGUES, 1963; CARVALHO et al., 2007), marsupials, rodents (SOLDAN \& MARQUES, 2011) and nonhuman primates (PINTO et al., 2017).

This trematode is found in tropical and subtropical regions and has already been reported in South and North America, 
Asia, Africa, Australia, the Pacific Islands, and the Caribbean (BASU \& CHARLES, 2014). In Brazil, it has been reported in cities in the southeast (RAGOZO et al., 2002), northeast (BRAGA et al., 2016), central-west (RAMOS et al., 2013), and south (MICHAELSEN et al., 2012) regions. It parasitizes domestic and wild cats, with a frequency of infection of $1.91 \%$ to $40 \%$ (BRAGA et al., 2016), but there is not record in the scientific literature of the occurrence of P. illiciens in the state of Tocantins, northern Brazil.

The biological cycle of $P$. illiciens is complex and requires intermediate hosts (terrestrial gastropod mollusks and terrestrial isopod) and a paratenic host (reptiles and amphibians) (BASU \& CHARLES, 2014; PINTO et al., 2014). Most parasitized domestic cats display no clinical signs, but at high parasite load, nonspecific signs can be observed, such as anorexia, vomiting, lethargy, jaundice, weight loss, hepatomegaly, abdominal distension, sialorrhea, petechiae, ecchymosis, and diarrhea (GAVA et al., 2015).

The laboratory diagnosis of platynosomiasis through coproparasitological examination is an important tool in veterinary clinical practice. Methods of sedimentation or flotation in a saturated solution of sugar, salt or zinc are used and although there is not still consensus as to the most suitable method for the recovery Platynosomum eggs in feline feces, some methods have a sensitivity of up to $100 \%$ (MATI et al., 2015; RAMOS et al., 2016). The objective of this study was to verify the occurrence of $P$. illiciens infection in domestic cats in the city of Araguaína, Tocantins, Brazil, using necropsy and coproparasitological tests. Additionally, we aimed to evaluate the use of two different techniques to diagnose P. illiciens in domestic cats and to verify the association of this parasitism with individual feline characteristics.

The study was carried out in the city of Araguaína, located in the Brazilian Legal Amazon, in the northern region of the state of Tocantins, Brazil (latitude $7^{\circ} 11^{\prime} 26^{\prime \prime}$ south, longitude 48 $12^{\prime} 28^{\prime \prime}$ west, and altitude $236 \mathrm{~m}$ ).

The material was collected from 54 domestic cats from the city of Araguaína, received by Zoonosis Control Center of Araguaína for euthanasia, and from dead animals referred for parasitological necropsy at the Laboratory of Animal Parasitology of UFT. The animals were euthanized according to the recommendations of the Brazilian Guidelines of Best Practices for Euthanasia of Animals (CFMV, 2012).

Animal age was estimated by dental evaluations, as described by Costa (2015) and the clinical signs observed were the presence of jaundice, hepatomegaly, abdominal distension, and weight loss, which are clinical signs observed in platynosomiasis. The livers were collected during necropsy and analyzed through a section of the bile ducts to verify the presence of trematodes. Animals with $\leq 125$ trematodes were classified as having a low parasite load and animals with $>125$ trematodes were classified as having a high parasite load, according to Rodriguez-Vivas et al. (2004). The technique described by Pinto et al. (2014) was used to fix and mount the specimens. Specific morphological characteristics were used to identify the specimens, according to the description by Rodrigues (1963).

Coproparasitological tests were performed using stool samples collected directly from the animal rectum during necropsy , which were preserved by refrigeration in a $10 \%$ formaldehyde solution until processing. Samples were processed using the spontaneous sedimentation (HOFFMAN et al., 1934) and Sheather's flotation (SHEATHER, 1923) methods.

The percentage of infection, abundance, and mean intensity were estimated according to Bush et al. (1997). The association between the infection by $P$. illiciens and individual animal characteristics was evaluated by univariate analysis and chi-square test. The association between parasitic load and coproparasitological test was evaluated by univariate analysis result by Fisher exact test using the Epi Info 3.5.4. statistical software (DEAN et al., 1990). The sensitivity and specificity of the coproparasitological methods were calculated in a contingency table using the Open Epi software (DEAN et al., 2013), whilst considering the necropsy findings as the standard test. This program provided the calculated values of sensitivity, specificity and Kappa value.

This study was approved by the Research Ethics Committee of the Federal University of Tocantins under protocol number 23101.001759/2016-42.

Fifty-four stray of cats were analyzed, of which 33 were females and 21 were males. Eighteen (33.3\%, CI = 21.1-47.5\%) livers had parasites with a flat body. Of the parasitized animals, $15(83.3 \%)$ were females and three $(16.7 \%)$ were males. The parasite load ranged from nine to 509 parasites, with a mean intensity of 151.7 , and a mean abundance of 50.5 trematodes per animal. Seven (38.9\%) of the 18 positive animals having a high P. illiciens load and $11(61.1 \%)$ low.

Of the 54 stool samples analyzed, $21(38.9 \%)$ were positive in at least one of the diagnostic methods used. The spontaneous sedimentation method highlighted P. illiciens eggs in 11 (20.8\%) samples. This method presented a sensitivity and specificity of $44.4 \%$ (8/18) and $91.7 \%$ (33/36), respectively. Sheather's method highlighted $P$. illiciens eggs in $10(18.5 \%)$ samples and presented a sensitivity and specificity of 22.2\% (4/18) and 83.3\% (30/36), respectively (Table 1 ). The concordance (Kappa value) between the tests and the necropsy was low. No association was found between parasite load and coproparasitological examination using the sedimentation method $(\mathrm{P}=0.352)$ or the flotation method $(\mathrm{P}=0.515)$. The analysis of the association between individual animal characteristics and the presence of $P$. illiciens in the liver is shown in Table 2. Only the sex variable was associated with P. illiciens presence.

The percentage of infection reported in this study was close to those percentages reported in some studies conducted in the Brazilian Legal Amazon which showed percentages of infection 26.03\% (RAMOS et al., 2013) and 38.3\% (RAMOS et al., 2017). These localities have in common belong to the tropical climatic zone of the Brazilian territory. The prevalence of P. illiciens reported in feline populations of tropical and subtropical countries varies between 15\% and 81\% (BASU \& CHARLES, 2014), which justifies the high frequency of parasitism found in our study. Likewise, the parasite load found in cats from Araguaína showed the same pattern of variation found in Brazil and other countries of tropics (RODRIGUEZ-VIVAS et al., 2004; BRAGA et al., 2016; RAMOS et al., 2017)

The low sensitivity of Sheather's test in the present study can be justified by the fact that P. illiciens eggs are heavy and the Sheather's test is a flotation technique, therefore, better diagnosed 
Table 1. Sensitivity and specificity of the Hoffman, Pons, and Janer and Sheather's tests for the diagnosis of Platynosomum illiciens in domestic cats from the city of Araguaína, Tocantins, Brazil.

\begin{tabular}{|c|c|c|c|c|c|c|}
\hline \multirow[b]{2}{*}{ Tests } & & \multicolumn{2}{|c|}{ Platynosomum in the liver } & \multirow{2}{*}{$\begin{array}{l}\text { Sensitivity } \\
\%(C I)\end{array}$} & \multirow{2}{*}{$\begin{array}{c}\text { Especificity } \\
\%(C I)\end{array}$} & \multirow[b]{2}{*}{ Kappa Cohen } \\
\hline & & $\begin{array}{c}\text { Yes } \\
\mathrm{N}=18\end{array}$ & $\begin{array}{c}\text { No } \\
\mathrm{N}=36\end{array}$ & & & \\
\hline \multirow[t]{2}{*}{ Hoffman } & + & $8(44.4 \%)$ & $3(8.3 \%)$ & $44.4(24.6-66.3)$ & $91.7(78.1-97.1)$ & $0.4(0.15-0.65)$ \\
\hline & - & $10(55.6 \%)$ & $33(91.7 \%)$ & & & \\
\hline \multirow[t]{2}{*}{ Sheather } & + & $4(22.2 \%)$ & $6(16.7 \%)$ & $22.2(9.0-45.2)$ & $83.3(68.1-92.1)$ & $0.06(-0.18-0.31)$ \\
\hline & - & $14(77.8 \%)$ & $30(83.3 \%)$ & & & \\
\hline
\end{tabular}

CI: Confidence interval (95\%); N: number of samples; +: positive; -: negative.

Table 2. Univariate analysis to determine the risk factors for Platynosomum illiciens infection in cats from the city of Araguaína, Tocantins, Brazil.

\begin{tabular}{|c|c|c|c|c|c|}
\hline Variables & $\mathbf{N}$ & Positive (\%) & OR & CI & $\mathbf{P}$ \\
\hline \multicolumn{6}{|l|}{ Sex } \\
\hline Female & 33 & $15(45.5 \%)$ & 5.0 & $(1.2-20.3)$ & 0.017 \\
\hline Male & 21 & $3(14.3 \%)$ & & & \\
\hline \multicolumn{6}{|l|}{ Age } \\
\hline Young & 3 & $1(33.3 \%)$ & 1 & $(0.1-11.8)$ & 0.712 \\
\hline Adults & 51 & 17 (33.3\%) & & & \\
\hline \multicolumn{6}{|l|}{ Body score } \\
\hline Good & 16 & $8(50.0 \%)$ & 2.38 & $(0.7-8.6)$ & 0.181 \\
\hline $\mathrm{Bad}$ & 27 & $8(29.6 \%)$ & & & \\
\hline \multicolumn{6}{|l|}{ Clinical signs } \\
\hline Yes & 17 & $6(35.3 \%)$ & 1.136 & $(0.3-3.8)$ & 0.836 \\
\hline No & 37 & $12(32.4 \%)$ & & & \\
\hline
\end{tabular}

$\mathrm{N}$ : number of samples; OR: Odds ratio; CI: Confidence interval (95\%); P: p value.

by sedimentation methods. The intermittent oviposition performed by this parasite in small quantities, also explains the low sensitivity obtained in the tests used in this study (LEAL et al., 2011). The use of the spontaneous sedimentation test is well-known in veterinary medicine for the research of heavy eggs, however, during the microscopic reading process, a large number of fecal debris may decrease the sensitivity of the test. The present study analyzed only one slide per animal, but to read at least three slides per feces sample can increase sensitivity (TIBIRIÇA et al., 2009; MATI et al., 2015). The loss or non-visualization of the hepatic parasites in animals with low parasitic load may justify the specificity values observed.

Female cats were more likely to be infected with P. illiciens than males $(\mathrm{OR}=5.0)$, a result also found by Rodriguez-Vivas et al. (2004), which can be explained by the frequent hunting to feed their offspring (SOLDAN \& MARQUES, 2011; GAVA et al., 2015). The age of cats and body score not considered as factors associated with the presence of $P$. illiciens in cats, which contrasts with the observations by Rodriguez-Vivas et al. (2004), who found that cats older then two years showed an increased probability of infection, however our result may have been influenced by the small number of young animals in sample. Adult animals tend to be more likely to be infected by $P$. illiciens due to the longer exposure time and hunting activity (SOLDAN \& MARQUES, 2011). In addition, the prepatent period ranges from 56 to 60 days (BRAGA et al., 2016), which may interfere with the diagnosis of young animals.
The body score was not considered a factor associated with the presence of $P$. illiciens in cats, agreeing with the observations by Rodriguez-Vivas et al. (2004). At least one clinical sign of platynosomiasis was found in six (35.3\%) animals parasitized by P. illiciens, but this was not statistically associated with infection.

In conclusion, $P$. illiciens is a parasite of the liver of cats living in Araguaína, Tocantins, Brazil. In this study, the spontaneous sedimentation test demonstrated the greatest sensitivity and specificity in the diagnosis of $P$. illiciens. The present study is the first to report the occurrence of $P$. illiciens in cats in the state of the Tocantins, northern Brazil.

\section{Acknowledgements}

We thank the Conselho Nacional de Ciência e Tecnologia do Brasil (CNPq), the Fundação de Amparo a Pesquisa do Tocantins, and the Universidade Federal do Tocantins for supporting our work.

\section{References}

Basu AK, Charles RA. A review of the cat liver fluke Platynosomum fatosum Kossack, 1910 (Trematoda: dicrocoeliidae). Vet Parasitol 2014; 200(1-2): 1-7. http://dx.doi.org/10.1016/j.vetpar.2013.12.016. PMid:24412358.

Braga RR, Teixeira AC, Oliveira JAA, Cavalcanti LPG. Prevalence of Platynosomum fastosum infection in free roaming cats in northeastern 
Brazil: fluke burden and grading of lesions. Vet Parasitol 2016; 227: 2025. http://dx.doi.org/10.1016/j.vetpar.2016.07.021. PMid:27523932.

Bush AO, Lafferty KD, Lotz JM, Shostak AW. Parasitology meets ecology on its own terms: Margolis et al. revisited. J Parasitol 1997; 83(4): 575583. http://dx.doi.org/10.2307/3284227. PMid:9267395.

Carvalho AR, Souza-Lima S, Daemon E, Tavares LER, Luque JL. Quantitative and morfometrical aspects in infrapopulations of Platynosomum illiciens (Trematoda: Dicrocoeliidae) in Paroaria dominicana (Passeriformes: Emberizidae) from the state of Bahia, Brazil. Rev Bras Parasitol Vet 2007; 16(4): 181-185. http://dx.doi.org/10.1590/S1984-29612007000400001. PMid:18373892.

Conselho Federal de Medicina Veterinária - CFMV. Guia Brasileiro de Boas Práticas em Eutanásia em Animais - Conceitos e Procedimentos Recomendados. Brasília: CFMV, 2012.

Costa RCB. Estudo epidemiológico da coinfecção por Toxoplasma gondii e pelo vírus da imunodeficiência felina em gatos domésticos (Felis catus) em Goiânia, Goiás [dissertação]. Goiás: Universidade Federal de Goiás; 2015.

Dean AG, Dean JA, Burton AH, Dicker RC. Epi Info: a general purpose microcomputer program for public health information systems. Am J Prev Med 1990; 7(3): 178-182. http://dx.doi.org/10.1016/S07493797(18)30936-X. PMid:1657068.

Dean AG, Sullivan KM, Soe MM. OpenEpi: open source epidemiologic statistics for public health Versão 3.1. [online]. 2013 [cited 2017 Jan 5]. Available from: https://www.openepi.com/Menu/OE_Menu.htm

Gava MG, Hiura E, Lopes ACG, Vieira FT, Flecher MC, Fonseca LA, et al. Platynosomum fastosum in na asymptomatic cat in the state of Espírito Santo: first report. Rev Patol Trop 2015; 44(4): 496-502. http:// dx.doi.org/10.5216/rpt.v44i4.39235.

Hoffman WA, Pons JA, Janer JL. The sedimentation concentration method in Schistosomiais mansoni. Puerto Rico J Public Health 1934; 9(1): 283-298.

Leal PDSA, Campos DP, Rodrigues MLA, Botelho GG, Labarthe NV. Avaliação da administração oral de ácido ursodesoxicólico (AUDC) no diagnóstico da infecção natural por Platynosomum illiciens em gatos. Rev Bras Med Vet 2011; 33(4): 229-233.

Mati VLT, Pinto HA, Melo AL. Evaluation of Kato-Katz and spontaneous sedimentation methods for the diagnosis of platynosomiasis in Neotropical primates. Rev Bras Parasitol Vet 2015; 24(1): 108-113. http://dx.doi. org/10.1590/S1984-29612015014. PMid:25909264.

Michaelsen R, Silveira E, Marques SMT, Pimentel MC, Costa FVA. Platynosomum concinnum (Trematoda: Dicrocoeliidae) em gato doméstico da cidade de Porto Alegre, Rio Grande do Sul, Brasil. Vet Foco 2012; 10(1): 53-60.

Pinto HA, Mati VLT, Melo AL. New insights into the life cycle of Platynosomum (Trematoda: dicrocoeliidae). Parasitol Res 2014; 113(7): 27012707. http://dx.doi.org/10.1007/s00436-014-3926-5. PMid:24802870.
Pinto HA, Mati VLT, Pujoni DF, Melo AL. Platynosomum illiciens (Trematoda: Dicrocoeliidae) in captive black-tufted marmoset Callithrix penicillata (Primates: Cebidae) from Brazil: a morphometric analyses with taxonomic comments on species of Platynosomum from nonhuman primates. J Parasitol 2017; 103(1): 14-21. http://dx.doi.org/10.1645/161. PMid:27762668.

Pinto HA, Pulido-Murillo EA, Braga RR, Mati VLT, Melo AL, Tkach VV. DNA sequences confirm low specificity to definitive host and wide distribution of the cat pathogen Platynosomum illiciens (= P. fastosum) (Trematoda: dicrocoeliidae). Parasitol Res 2018; 117(6): 1975-1978. http://dx.doi.org/10.1007/s00436-018-5866-y. PMid:29707742.

Ragozo AMA, Muradian V, Silva JCR, Caravieri R, Amajoner VR, Magnabosco C, et al. Ocorrência de parasitos gastrintestinais em fezes de gatos das cidades de São Paulo e Guarulhos. BrazJ Vet Res Anim Sci 2002; 39(5): 244-246. http://dx.doi.org/10.1590/S1413-95962002000500005.

Ramos DGS, Santos ARGLO, Freitas LC, Braga IA, Silva EP, Soares LMC, et al. Feline platynosomiasis: analysis of the association of infection levels with pathological and biochemical findings. Rev Bras Parasitol Vet 2017; 26(1): 54-59. http://dx.doi.org/10.1590/s1984-29612017009. PMid:28327881.

Ramos DGS, Scheremeta RGAC, Oliveira ACS, Sinkoc AL, Pacheco RC. Survey of helmith parasites of cats from the metropolitan area of Cuiabá, Mato Grosso, Brazil. Rev Bras Parasitol Vet 2013; 22(2): 201-206. http:// dx.doi.org/10.1590/S1984-29612013000200040. PMid:23856737.

Ramos RAN, Lima VFS, Monteiro MFM, Santana MA, Lepold R, Faustino MAG, et al. New insights into diagnosis of Platynosomum fastosum (Trematoda: Dicrocoeliidae) in cats. Parasitol Res 2016; 115(2): 479-482. http://dx.doi.org/10.1007/s00436-015-4763-x. PMid:26437646.

Rodrigues HO. Contribuição ao estudo do gênero Platynosomum Loos, 1907 (Trematoda, Dicrocoeliidae). Mem Inst Oswaldo Cruz 1963; 61(3): 507-515. http://dx.doi.org/10.1590/S0074-02761963000300008. PMid:14141131.

Rodriguez-Vivas RI, Williams JJ, Quijano-Novelo AG, Bolio GME, Torres-Acosta JFJ. Prevalence, abundance and risk factors of liver fluke (Platynosomum concinnum) infection in cats in México. Vet Rec 2004; 154(22): 693-694. http://dx.doi.org/10.1136/vr.154.22.693. PMid:15200076.

Sheather AL. The detection of intestinal protozoa and mange parasites by a flotation technique. J Comp Pathol Ther 1923; 36: 266-275. http:// dx.doi.org/10.1016/S0368-1742(23)80052-2.

Soldan MH, Marques SMT. Platinosomose: abordagem clínica felina. Rev FZVA 2011; 18(1): 46-67.

Tibiriça SHC, Abramo C, Simões AS, Pinheiro IO, Ribeiro LC, Coimbra ES. Validação do número de lâminas para realização do método de sedimentação espontânea das fezes. HU Rev 2009; 35(2): 105-110. 